\title{
Making education on sustainable community planning tangible
}

\author{
U. Rydningen ${ }^{1,2}$ \& C. Nordahl-Rolfsen ${ }^{1,2}$ \\ ${ }^{1}$ Department of Civil Engineering and Energy Technology, Oslo, Norway \\ ${ }^{2}$ Akershus University College, Norway
}

\begin{abstract}
Sustainable development is a global issue, but for many people it is most meaningful to discuss sustainability at the local level, where people live their daily lives. Civil and environmental engineers (CEE) most often are dealing with local level tasks, and their designs are influencing human behaviour and thereby having an impact on the local communities' sustainability outcome. This paper describes Norwegian CEE students' experiences, gained from guided study-tours to Copenhagen and Malmö during the past three years. An annual three-day studytour is arranged as part of three simultaneously offered courses: 'Integrated Land Use and Transport Planning', 'Environmental Engineering' and 'Architecture Theory and History'. The purpose of this study is to investigate which learning outcomes our students had from the urban districts visited, and how they evaluate the sustainability measures witnessed. Auditing is based on the students' knowledge acquisition from these three courses and previous courses through their studies. From their case-studies in Örestad (Copenhagen) and Western Harbour (Malmö), the students' group reports are describing themes like local climate, human scale, traffic safety, urban drainage systems (SUDS), landscape and open spaces, green roofs, crime prevention (CPTED), and universal design. By walking around, students become aware of qualities that should be implemented in local planning and design processes. From the students' group reports we can see that students are able to reflect on local sustainability outcomes, recommend further improvements and discuss their results related to sustainability theories and planning history.
\end{abstract}

Keywords: engineering education, sustainable urban development. 


\section{Introduction}

Although sustainable development is a global issue, to achieve a sustainable community, we need politicians expressing their visions and values in discussions and decisions on urban planning. Planners are also important for enlightening and bringing their professional knowledge and ideas into local sustainable development discussions. Many of these local sustainability aspects are relevant in the curriculum of civil and environmental engineering (CEE) studies, in order to prepare students for their future as influential professionals. Traditionally, the branch of civil and environmental engineering has covered sub-disciplines like, among others, transportation planning, urban planning, highway engineering, waste, water and wastewater engineering, and building physics. These are all relevant and essential core topics in planning for sustainable urban communities. During the latest decades, some interesting sustainable urban developments like Curitiba in Brazil [1-4] and Bogota in Colombia [5, 6] have become famous worldwide as examples and inspiration in educating transportation engineers, urban planners, landscape architects, and architects. Curitiba has the highest recycling rate in the World $(70 \%)$, a bus system that is so good that road traffic decreased by $30 \%$ while the population trebled over a twenty-year period. Further Curitiba has the largest downtown pedestrianised shopping area in the World, and Curitiba has built a large number of beautiful parks to control floods, rather than concrete canals. Conclusively, inhabitants say they like living in Curitiba, and its long term development for urban sustainability seems to promote a high quality of life.

All local sustainable communities have different preconditions and need to be planned according to these, subsequently the urban sustainability measures that will be implemented will vary greatly. This paper describes results based on guided study tours with CEE students to Copenhagen and Malmö over the past three years as part of three simultaneously lectured undergraduate courses at Oslo and Akershus University College in Oslo, Norway, namely 'Integrated Land Use and Transport Planning', 'Environmental Engineering' and 'Architecture Theory and History'. This paper investigates how our students evaluate the sustainability outcomes in two urban districts, based on the students' own observations of implemented measures in the built environment in Örestad (Copenhagen, Denmark) and the Western Harbour (Malmö, Sweden). Auditing is based on their knowledge acquisition from these courses and previous courses through their studies.

\section{Sustainable urban communities: what is essential to learn}

Williams [7] questions "do we know what the sustainable city is?" She claims that in reality, most disciplines working in the field of sustainable cities construct their own notion of what the concept means for them. In engineering, the sustainable city is defined when resources are used most efficiently [7]. This corresponds with many engineering studies emphasising knowledge development on LCA, but urban planning has also been a traditional subject of the civil engineering 
education $[8,9]$. Below we will describe some planning theories that we focus on especially during lectures in the land use and transport planning course.

Certain elements are often considered to be the main aspects of any community, including 1) land use, density and layout, 2) transportation, 3) buildings, 4) landscape and open space, 5) infrastructure (energy, water and solid waste) and 6) economic investment, jobs and businesses. These items are also traditional core knowledge in many CEE and planning education curricula. Nowadays it is important to include knowledge relevant for sustainable communities to $\mathrm{CEE}$ courses, with issues like reducing car dependency (mobility management, improving public transport, parking policies), developing sustainable buildings (green buildings, passive houses), and considering alternative location strategies such as infilling, extension, linear development, sprawl and/or large-scale projects [10]. The planning of sustainable urban communities represents an important overarching goal and a long term vision for the future [11]. By the year 2030, about $60 \%$ of the world's population will live in cities, and it is essential to develop new urban districts in a heedful way. Are there common characteristics of sustainable communities, and which criteria must then be met in order to say that we have achieved a sustainable community? There are several delineations of what a sustainable community or urban sustainable development may be. Berke and Conroy [12] argue that land use plans should be developed based on six long-range sustainable development principles. These are:

1) Harmony with nature - land use and development supporting ecosystem processes;

2) Liveable built environment - development enhances fit between people and urban form;

3) Place-based economy: local economic activity operates within natural system limits and meet local needs;

4) Equity - land use patterns provide equitable access to social and economic resources;

5) Polluter pays - those who cause pollution bear its cost;

6) Responsible regionalism - communities minimizes harm to other jurisdictions in pursuit of local goals.

When teaching CEE students about sustainable urban development, there are several different approaches to planning our communities in a sustainable manner. Three concepts are indirectly related to sustainability and provide some alternative paths towards this goal [13]. 'Smart Growth' promotes compact, mixed-use development that encourages choice of travel mode (walking, cycling, transit and autos) by coordinating transportation and land use, requires less open space, and gives priority to maintaining and revitalizing existing neighbourhood and business centers. 'New Urbanism' is, relative to Smart Growth, more architecturally prescriptive and detailed in specifying the physical layout of a community in which design, scale, land use mix, transit oriented development (TOD), and street-network elements dominate. Members of the Congress for the New Urbanism (CNU) adopted a charter in 1996 which basically is a design manifesto that lays out twenty-seven principles for three scales of development. The concept of 'the ecological city' (Ecocity) is understood to describe processes 
which will ensure that a city can carry out its basic functions (i.e. taking care of its inhabitants' basic needs etc.) in an ecologically sensitive manner without risking the possibilities of the future generations to take care of their needs [14]. Jepson and Edwards [15] suggest the planning profession to define some sort of hybrid approach that combines characteristics of 'Smart Growth', 'New Urbanism' and 'the ecological city'. For example, while the smart growth approach may achieve a better job - housing balance, it is likely to leave sense of place unaddressed. And while new urbanism may fulfil that dimension, it is not viewed as an approach that will lead to communities that are self-reliant, which is more likely under an ecological city approach [15]. In addition to the core CEE competencies mentioned in the beginning of this chapter, there are other competencies that are also important for CEE when planning sustainable communities.

"There is always an author, the planner as policy analyst, who is choosing which facts are relevant, what to describe, what to count..." [16]. The planner's knowledge is essential to which facts and values are presented into the planning process. Traditionally, one part of the planner's knowledge is about planning history. We may justify teaching planning history for several reasons; one is that planning history emphasises the importance of knowing the background of specific problems or issues. This argument is a bureaucratic version of George Santayana's epigram about learning history to avoid repeating past errors. Another justification of use of historical perspective is to place policies in time by understanding how they have evolved through the implementation process [17].

In her writing Jane Jacobs (1996) was concerned about the problems of city planning and urban renewal, and she especially focused on people, analysed urban neighbourhoods, and described some principles that should guide urban design: mixed-use, density and permeability. According to Jacobs, a mix of different activities would make a place more lively. If a neighbourhood has some offices, and shops in addition to dwellings, there will always be people on the street, "eyes upon the street", which create safer neighbourhoods. Jacobs was also one who wanted us to build taller buildings. The argument for this was that a high building density allows for people becoming less dependent on car use because, coupled with mixed functionality, reduced car use, creates less air pollution, less area to parking lots and improved public health. Jacobs did not only blame the city planners, but she also placed the burden of the blame on the theorists and educators. Jane Jacob's ideas are a forerunner of Smart Growth, in which cities are concentrated at the core, automobile use is reduced and nature outside the confines of the city has a chance to flourish.

The Danish architect professor and urban planner Jan Gehl gives in the book "Life between houses" [18] a clear and simple message: "It is the space between the houses we meet spontaneously". In outdoor areas of poor quality, we make only the necessary actions, while in high quality outdoor spaces we make also a number of optional activities. Like Jane Jacobs he argues that "housing in the city, along with retail, gives more life and well-being than just shops". In city and local development, we must investigate and understand what people actually do, how they act and how they relate to each other and their surroundings. Gehl provides 
many detailed solutions, e.g. that meeting places must be built so that people can see each other and create social contact.

\section{Fieldwork}

Field trips give students the opportunity to convert theoretical knowledge into practice. Even in small groups, up to 20 students, problems can arise because not everyone can hear or see the guide. Using wireless guided-tour systems makes it possible to arrange guided tours for exhibitions and cities, ensuring that every participant at least will hear the guide, even in loud environments. A wireless tour guiding system was used at the last study tour in the autumn of 2015. Students study tour audits is part of the course examination in the course 'Integrated Urban and Transport Planning', and quite early in the semester students form groups where each group member takes a role (e.g. group leader, architect, urban planner or infrastructure planner). Students are asked to select data collection methods for their field reports, choosing between SWOT-analysis, PhotoVoice [19], interviews, photographs, sketching, and/or indicators, for auditing and evaluating urban sustainability measures. All groups illustrate their observations with photographs, and many groups make some additional literature review after the field trip, while completing the field report. All students are also obliged to submit individual reflective essays at the end of the course period, as part of the formative course assessment. In these reflective essays, the students often write about their experiences and the learning outcomes from the fieldwork. During these three study trips, totally 66 students participated and they formed 21 groups (table 1).

Table 1: $\quad$ Students participating in field trips to Copenhagen and Malmö.

\begin{tabular}{lccccc}
\hline & & Spring 2014 & Autumn 2014 & Autumn 2015 & Total \\
\hline Students & & 24 & 23 & 19 & 66 \\
& Male & 16 & 16 & 13 & 45 \\
\multirow{4}{*}{ Groups } & Female & 8 & 7 & 6 & 21 \\
\hline
\end{tabular}

Table 2: Data collection methods used in field reports.

\begin{tabular}{lccccc}
\hline & $\begin{array}{c}\text { SWOT- } \\
\text { analysis }\end{array}$ & Photo/sketches & Interviews & $\begin{array}{c}\text { Literature } \\
\text { review }\end{array}$ & Indicators \\
\hline $\begin{array}{l}\text { Field } \\
\text { reports }\end{array}$ & 6 & 21 & 4 & 14 & 0 \\
\hline
\end{tabular}

All student groups illustrated their field reports with photos. No groups can be said to have carried out the PhotoVoice method as it is expected to be performed, indicating a need for better briefing on this method. SWOT-analysis were often used as a supplementary method to other methods, while one group delivered only a short SWOT-analysis without further report content. Literature reviews were performed as part of $2 / 3$ of the group reports.

The study tour opens with gathering at a hotel in Örestad City, where we begin with telling about Örestad development plans over an architectural model of the 
Örestad district as it will be, fully developed in year 2031. Then we do a guided walking tour through Örestad City, before taking the Metro to Örestad North. After a guided walking tour of Örestad North, we take the metro up to Örestad South. After a late joint lunch, students are released to do supplementary examinations and interviews on their own. The next day we take the train to Sweden (30 min journey) and start with inspecting the urban development area Hyllie with the Emporia Mall, which has a large green roof garden. After lunchtime, we continue our train journey to Malmö Central Station and walk from there to Western Harbour, returning early in the afternoon back to Copenhagen. On the third day, after first a guided tour of the Ramböll headquarters, the students are free to walk around to perform supplementary field registrations or to start with their report writing.

\subsection{Urban districts}

Figure 1 shows Örestad Urban District, and figure 2 shows the Western Harbour, both marked with red frames. In figure 1, we can see to the right the Copenhagen Airport, and to upper left the Copenhagen city centre. Malmö city centre is southeast of the Western Harbour.

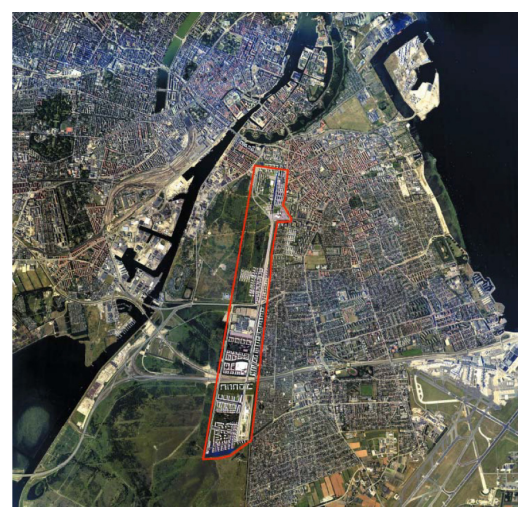

Figure 1: Örestad, Copenhagen.

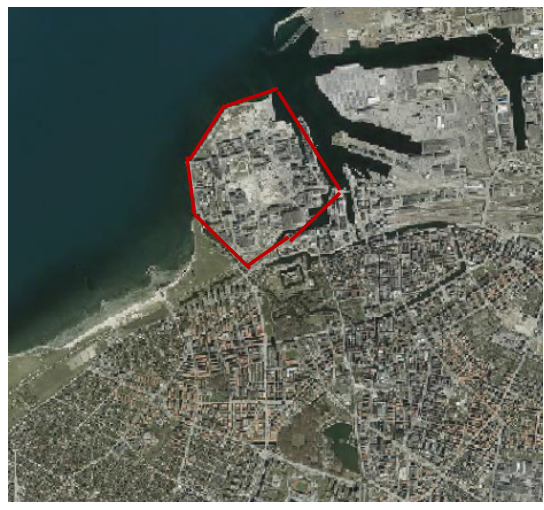

Figure 2: Western Harbour, Malmö.

Table 3: Characteristic information about the two urban districts.

\begin{tabular}{lll}
\hline & Örestad, Copenhagen & Western Harbour, Malmö \\
\hline Distance to city center & $1.5-6.5 \mathrm{~km}$ (Örestad North/South) & $2.0 \mathrm{~km}$ (Turning Torso) \\
Travel time to city center & $10 \mathrm{~min}$ with Metro (Örestad City) & $17 \mathrm{~min}$ with bus \\
Area & $5 \mathrm{~km} \times 0,6 \mathrm{~km}$ (310 ha) & $217 \mathrm{ha}$ \\
Density (2015) & $27 \mathrm{inh} . / \mathrm{ha}$ & $34 \mathrm{inh} . / \mathrm{ha}$ \\
Inhabitants (2031) & 30000 & 25000 \\
Jobs (2031) & 50000 & 25000 \\
\hline
\end{tabular}

Örestad urban district consists of four neighbourhoods, which are at different stages of development. Closest to the city centre is Örestad North, then Amager 
Commons, Örestad City and nearest to the Copenhagen airport we find Örestad South. The neighbourhoods Örestad North and Örestad City are almost completed while much urban development remains to be done in the other two neighbourhoods. The Örestad Master Plan from 1995 has been the main outline for developing the new districts. The idea of Örestad was to create a modern counterpart to the old Copenhagen city centre, following newer strategies for urban planning and creating possibilities for having a lot of new and modern architecture gathered in the district [20].

Western Harbour is originally a closed down industrial area. Renewal of this brownfield started with the BO01 neighbourhood, located close to the sea. Turning Torso, a famous landmark in Malmö, marks the entrance to this neighbourhood, which was completed for a housing exhibition in 2001. The urban development in the Western Harbour district has followed five principles: $100 \%$ locally produced renewable energy, meeting spaces, knowledge centre, mixed land use, and activity. These five principles will form the basis of human relationships, where people with different backgrounds and ideas can meet and coexist. The Western Harbour urban development strategy is based on much of the same principles that underlie the 'Smart Growth' and 'Ecocity'.

\subsection{1 Örestad, Copenhagen}

The Copenhagen Municipality has made prognoses telling that the capital's population will grow by 21 percent during the next 15 years, and it is to a great extent the new urban areas that are going to play a major role in this urban growth. Among the capital's ten districts the Örestad, North Port, and Vesterbro/Kgs. Enghave are those which will account for by far the greatest part of the growth with up to 20,000 new residents each, in 2027. Since the development of Örestad began 15 years ago 8,500 people are now living there. It is especially the young families, who see the benefits of moving to Örestad. Compared with the rest of Copenhagen, the proportion of the 20-39 cohort is about 15 percentage-points larger in Örestad and the proportion of 0-4-year-olds is almost twice that of the rest of the urban area. Residents emphasize the importance of the open skyline, modern apartment buildings and easy access to 'old' Copenhagen. Companies moving to Örestad are primarily attracted by the location. The Öresund motorway and railway passes through Örestad City and provides good accessibility to Copenhagen Airport and the Öresund Bridge to Malmö in Sweden. (By og Havn, 2012).

\subsubsection{Western Harbour, Malmö}

Demographic data on the population of Western Port in Malmö shows that an average inhabitant is an official in the age group of 30-40 years, and the level of education is high. For Malmö as a whole about 30 percent has achieved a postsecondary education, while at Western Harbour an astonishing 72 percent of respondents in a survey told that they had studied at college or university. The majority of Western harbour households consist of two persons ( 72 percent) while only 16 percent are living alone, compared to the overall rate for Malmö where 


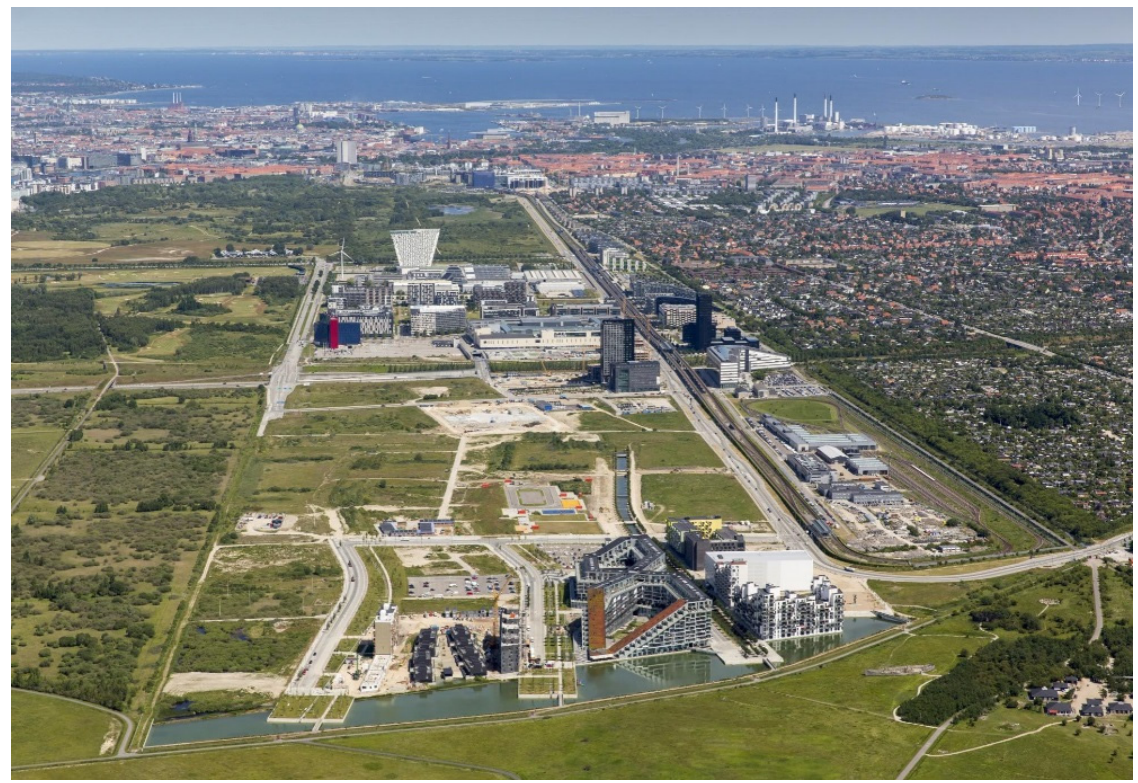

Figure 3: Örestad District in Copenhagen.

nearly 50 percent live alone. A 2004 survey showed that there were few who claimed to have chosen the area because of its environmental profile. The majority (56 percent) mentioned they had chosen to move to the area because of its proximity to the sea, and just two percent agreed that they chose the area because of its ecological neighbourhood profile. In 2031 the Western Harbour is expected to have around 25,000 residents and as many workplace employees.

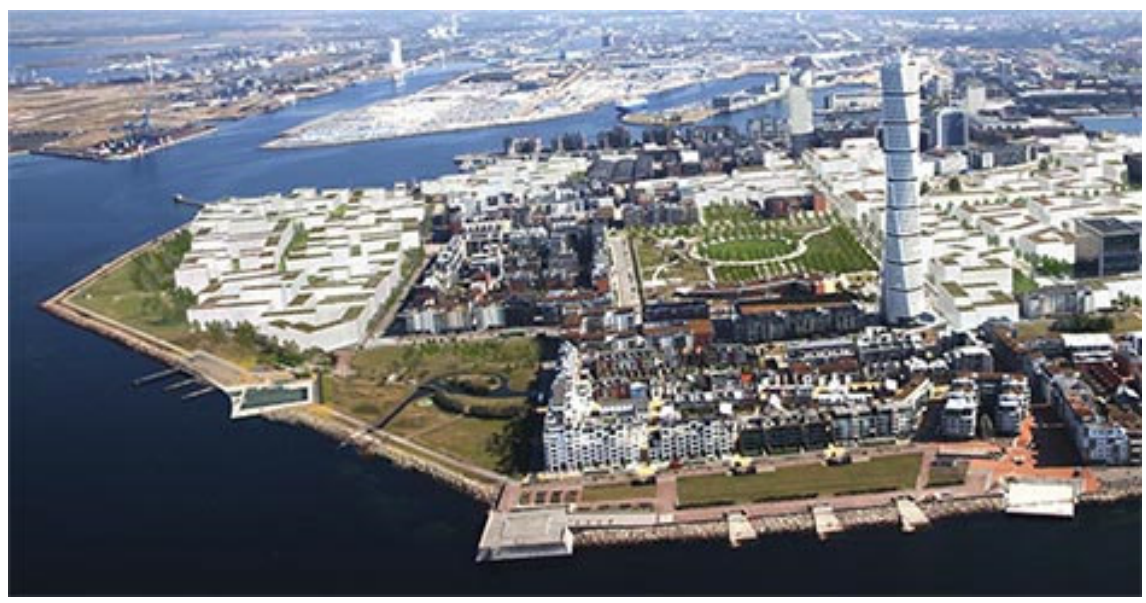

Figure 4: Malmö, Western Harbour. 


\section{Sustainability items identified by students}

In this section we get examples of what the students have found in the field trips as mentioned in their reports.

Table 4: Frequency of sustainability themes discussed in students' group reports, during study trips spring and autumn 2014 and autumn 2015.

\begin{tabular}{lrrrrrr}
\hline & \multicolumn{1}{c}{ 2014 Spring } & \multicolumn{2}{c}{ 2014 } & Autumn & 2015 & Autumn \\
\hline Stormwater/precipitation & 4 & $(4 \%)$ & 13 & $(3 \%)$ & 27 & $(4 \%)$ \\
$\begin{array}{l}\text { Landscape/natural } \\
\text { environment }\end{array}$ & 0 & $(0 \%)$ & 2 & $(0 \%)$ & 2 & $(0 \%)$ \\
Mixed land use & 2 & $(2 \%)$ & 31 & $(7 \%)$ & 65 & $(11 \%)$ \\
Malls/stores/businesses & 20 & $(19 \%)$ & 34 & $(7 \%)$ & 33 & $(5 \%)$ \\
Metro/public transit & 18 & $(17 \%)$ & 34 & $(7 \%)$ & 37 & $(6 \%)$ \\
Bicycling/walking & 9 & $(9 \%)$ & 18 & $(4 \%)$ & 67 & $(11 \%)$ \\
Architecture/building & 15 & $(14 \%)$ & 33 & $(7 \%)$ & 17 & $(3 \%)$ \\
Human scale/Jan Gehl & 2 & $(2 \%)$ & 104 & $(22 \%)$ & 87 & $(14 \%)$ \\
Traffic safety & 0 & $(0 \%)$ & 6 & $(1 \%)$ & 4 & $(1 \%)$ \\
Security/CPTED & 2 & $(2 \%)$ & 21 & $(5 \%)$ & 5 & $(1 \%)$ \\
Local climate/wind & 6 & $(6 \%)$ & 30 & $(7 \%)$ & 49 & $(8 \%)$ \\
Universal design/ & 7 & $(7 \%)$ & 77 & $(17 \%)$ & 111 & $(18 \%)$ \\
disabled persons & & & & & & \\
Work/employment & 0 & $(0 \%)$ & 1 & $(0 \%)$ & 9 & $(1 \%)$ \\
$\begin{array}{l}\text { New urbanism/TOD/ } \\
\text { Eco-City }\end{array}$ & 2 & $(2 \%)$ & 19 & $(4 \%)$ & 43 & $(7 \%)$ \\
Green spaces/ & & & & & & \\
green roofs & 18 & $(17 \%)$ & 43 & $(9 \%)$ & 56 & $(9 \%)$ \\
& & & & & & \\
\hline
\end{tabular}

Fifteen sustainability issues were identified by the student evaluators. Table 4 gives an overview of the frequencies with which these issues are mentioned in the students' field reports, and gives an indication of what our CEE students emphasise when walking around. Mixed land use and universal design are sustainability terms most often mentioned in the student reports. A growing focus has been to evaluate topics like mixed land use, bicycling/walking, New Urbanism/Ecocity and TOD. Despite a slight decline last year, students are highly focused on human scale, a term especially described by Jan Gehl and Jane Jacobs.

\subsection{Harmony with nature}

Land use and development supporting ecosystem processes are frequently mentioned in the students' field reports. Many students are interested in SUDS and one group comments on stormwater management in this way:

A feature of Western Harbour we observed, was the stormwater management. Stormwater is transported through small channels along the roads, as nourishment to plants and parkland along the walkways. A side effect of this, 
which we perceived as positive, was that area's connection to the sea along with stormwater management, giving a feeling that one is not in a busy urban area. Then you have the smell of sea air and the sound of running water in the background. Here one feels not small or great, but with the environment.

Another group mentioned:

Western Harbour is adjacent to sea. Much of the stormwater from Western Harbour is led directly out to sea using stormwater drains. From an area farther away from the ocean, stormwater is led into a channel. Within the Western Harbour district there are small green spaces and some green roofs that helps with stormwater storage. These are examples of environmentally friendly technologies where respect for ecology and natural systems are highly regarded. Most of the buildings in the Western Harbour have either extensive or intensive green roofs. This is something that is required in regulatory provisions for the district.

\subsection{Liveable built environment}

A development that enhances fit between people and urban form, has engaged the students interest. As table 4 shows, the issue of human scale from the theories of Jan Gehl was something the students often commented:

The quarters of the area are large, square and contain grandiose buildings. The large buildings and the long straight roads give a sense of loneliness and emptiness. Although the buildings are designed by world famous architects and they are very beautiful to look at separately. But together they make the area feel anonymous and uniform. It may seem like the area is planned for buildings and not for life as described by Jan Gehl. We guess one had a vision, then built according to this and then hoped that the people agree, rather than the other way around - finding out what people need, to satisfy the need.

Other observers confirm our students' experience with the Örestad human scale:

The visual experience is important. In order to get the necessary amount of visual stimuli, we need to experience a place of interest. The quarter's dimensions in Örestad is too large and the facades varying too little. At a distance the architectural concept area look well with green areas, modern architecture and excellent public transportation with the track-mounted Metro. Once in place in the area we are struck by the large scale and the monotonous design. During the day the quarters with apartment blocks is almost empty and the people life is between the Metro Station, the large department store and the offices next door. The monotonous design and long straight sight lines reinforces the feeling that the area is bigger than it really is. To go along a uniform facade of 100 meters, is not stimulating (Simonsson, 2010, p. 22)

\subsection{Local climate}

The local climate in Örestad is windy, and as a pedestrian you are particularly vulnerable. The large buildings that take up entire quarters increases the wind 
pressure and pushes the wind down between the buildings. One student commented:

I have not really thought about the height of the buildings before but when I experience the strong winds forces that can occur, this is certainly something I shall consider. I also got a better understanding of how much the building design has to say for the street life. I read in a report from the Crime Prevention Council; 'Better planning - fewer risks' and could therefore contribute with perspectives on how the area should be better arranged for security reasons.

From their reading of the course literature some students commented on the contrast between the development of Örestad to the traditional design of the Italian mountain villages. These are designed with frequent twisting streets to protect against wind and take advantage of the heat from the neighboring houses. The placement of the houses along the curved streets that follow the terrain provides a greater stimulus than the long straight lines of sight, and people stop to meet (Gehl, 2001, p. 40). Students noted that the Örestad planners seem to have forgotten the discipline's history.

Several other student groups have also commented on the local climate:

Orrestad is built with large open spaces that provide a lot of daylight and good visibility. The aim of this is to create space for an active urban life and facilitate the human factor. In Örestad several apartment buildings were equipped with balconies that were positioned so that they made full use of sunlight and solar heat. Due to high buildings there are some areas that much of the day do not get access to sunlight. It seems as if the buildings' architectural design stops at the front door, in that there is no flow in the transitions between the built-up area and public grounds. Negative aspects of microclimate thereby reinforced by the microclimate are not taken into account. Denmark is known for its flat landscape and windyness in most parts of the country. This requires good area planning, especially for areas that are particularly vulnerable. For Copenhagen, the average wind velocity (5.5-6.5 $\mathrm{m} / \mathrm{s})$ is higher compared to Oslo (3-4 m/s) (Windfinder, 2014), and hardly accounted for in Örestad. Long, straight streets create tunnel effects, and high houses create wind gusts.

The Western Harbour in Malmö has low buildings with narrow streets. This provides comforable surroundings and minimal wind gusts. In the streets there are planted trees and bushes which act as 'windbreakers' for any tunneling effects. The area closest to the sea is naturally somewhat exposed to the wind. This is because the area is very open and flat which makes it very accessible to the weather. We experienced the neighborhood as warm and pleasant because of the narrow streets.

The local climatic conditions are taken much more into account in the Western Harbour than in Örestad. These are issues that can be improved with increased population, yet we believe that this should be taken more into consideration during the development of new areas. This makes it attractive to be in the area and one experiences it as good to stay there. 


\subsection{Place-based economy}

Many students commented on the lack of businesses in Örestad City Center, almost every store in this neighborhood is located to the Field's mall. Some students interviewed people they met on the street and asked about what could be the reason for Örestad City lacking shops on the ground floor of the buildings. One of the respondents replied: "When showing interest for establishing in the neighborhood, Field's had got an agreement with the Copenhagen municipality that most business activities would take place at the mall". Sangild [21] confirms this in his blog: "Why are there no stores in Örestad North?":

So far, I ascribed it to the lack of attention from urban planners and thought that it would be further development. But today I was told by a colleague that there is another reason. There was originally specified a certain area for shops in Örestad. This area corresponds roughly to the large block with a foolish apostrophe called 'Field's'. Field's has all retail space in Örestad. Field's has been promised that there will be no stores throughout Örestaden (a gigantic area) so that they are assured a lack of competition. Field's are protesting every time someone shows interest in opening even the smallest shop.

Within Örestad district there is now established a university, a student dormitory, a congress hall, several hotels and other businesses. A guided visit to the headquarters for the consultant company Ramböll is part of our annual study trip, since the headquarters is constructed according to sustainable building principles. Students asked our local guide at Ramböll whether their employees live in the area. "We cannot imagine staying here. It's nice to work here, but we think it's a bit deserted and would rather stay in the older part of Copenhagen where there is more life in the streets".

\subsection{Equity}

Universal Design is an issue mentioned often in the students' reports. One group reflected on this, and wrote:

Örestad is a relatively new district and is expected to be fitted with new and smart architecture and design solutions, both in private and public buildings and spaces. In such a modern district it is anticipated that everything is taken into account. Although there is a lift in all buildings, automatic doors and flat entrances, parks and public areas are not perceived as well organised regarding accessibility.

Another group commented on the quality of the pavement, and confirms the idiom "the devil is in the details" expressing the idea that whatever one does should be done thoroughly; i.e. details are important:

On inspection we found that the pedestrian crossing green light lasted a very short while. This is a challenge for people with disabilities when they have no refuge island to wait on for the next green light phase. Subway and train stations had leading lines, lifts and used contrasting steps. This is of great help for orientation and mobility. Sidewalks consist mostly of large cobblestones. This creates problems for the white cane (cane mobility) that the blind and visually impaired use, because it can get stuck between stones and small 
bumps. People using a disability walker must also use more energy to walk, as irregularities will create more friction than a flat, hard surface. Edges in the transition between different surfaces and uneven stone slabs, can provide low vision challenges when even non-disabled have to pay attention to the pavement to avoid stumbling.

\subsection{Polluter pays}

At our visit at the Ramböll headquarters students asked about the employees' travel mode choice. Our guide explained that very few employees take their own car to work, most run by Metro, or bicycles. "If you drive your own car to work, one must pay a daily parking fee. But, if you bring your bike then there are locker rooms with showers available, safe indoor bicycle parking and the opportunity for maintenance and cleaning of the bike".

\subsection{Responsible regionalism}

Worked out in 1947 the 'Finger Plan' became a representation of modern state-led planning in Copenhagen. Especially after the Second World War the plan successfully helped control suburbanisation in corridors around infrastructural veins that were connected to central Copenhagen by a rail system. In between the linear suburban developments, green zones prospered. It was the 'regional plan committee' under the state that formed the layout of the Finger Plan, and their initial inspiration for the plan was found in Abercrombie's 'Greater London Plan 1944'. In many ways the development of Örestad epitomized a break with the original Finger Plan. First of all, the orientation of development was altered pointing eastwards towards Malmö away from the fingers, secondly the planning of Örestad reflected the changed role of the state - now working in closer relation to private investors. [22].

The regional role of Örestad and its public transit system was mentioned by the students. One group wrote:

Orestad is developed around the southern part of the metro line M1 and corresponds to TOD principles. The metro arrives every four minutes during rush hour. Along Örestad Boulevard run three different bus lines and by the metro stop in Orestad City is also a train station where you can easily reach both the city center, the airport and beyond in Denmark and Sweden. By the four metro stations in the Örestad district there are car parking spaces with fees and large bicycle parking spaces, so the metro is available for those who live some distance away.

\subsection{Affordability, economic investments and businesses}

Discussions about Örestad often occur in Danish media. In 2010 a newspaper columnist wrote [23]:

Another 20,000 locals is planned to settle in Örestad district. Several experts warn about the Örestad development repeating urban planning errors from the past. This development will slowly evolve towards an additional ghetto 
formation in Copenhagen. While politicians, scientists and architects are trying to find the key to reversing the direction of today's Danish ghettos, they build in Copenhagen a new prestige project with blocks that should be nice luxury for the middle class, close to both city and nature. A project which, according to several experts, has so many features in common with the neighborhoods which today ended as ghettos that they call Örestaden "a poor city that game is over for". More than anything, Örestad has been built in the middle of a construction boom, and this has contributed to the apartments being very expensive - whether you buy or rent.

\subsection{Reflections on the study trip}

Most responses to the walking tour have been very positive, though some varied responses to the planned tour arrangement are evoked:

My academic progress has been pretty good. I feel like I've learned more from working with the projects, than the lectures. But mostly, I have probably learned from study tours, although I think that the Copenhagen trip could have had a little more professional content. There became a lot of fumbling around on our own. But the social atmosphere became better from this study trip, of course.

This refers probably to the fact that the students got some dedicated time to self-guided auditing the last day to supplement their field studies.

One student commented in his reflection note on the field trip:

Of all field trips we attended, this one was for sure the most social and educational I encountered in this course. We took some pictures of the areas we inspected, and it was very exciting to see what urban planning can do with well-being in a city. Everyone in the class became also much better acquainted during the field trip to Copenhagen and Malmö.

The learning outcome of being able to see and touch implemented measures in real life was commented by several students:

It was very interesting to see two distinct neighbouring cities to be so different. The arrangement of the trip was very good and it was easy to see the connection between what we saw on the auditing and what we have learned in the lectures. I feel that there are huge learning benefits of being able to see practical examples in real life and not just the slides from PowerPoint.

I have noticed that the study trips, since they are related to the course content, are of greater importance than what I first thought. It helps a lot to see the sites with our own eyes. These study trips have not only led to more professional understanding, but also a good social environment in the class. This enhances the learning environment when you cooperate and discuss tasks in groups. The study tour to Örestad and Western Harbour gave a little more overall view of what may contribute to successful sustainable urban development.

Formal education and training is extremely important but learning takes place in a variety of settings, as confirmed by these students. 


\subsubsection{Recommendation to further development in Örestad and Western Harbor}

Students were also asked to make some suggestions for further improvements of these urban districts, based on their theoretical and practical knowledge acquisition. One of the groups commented:

First priority of Örestad, would have to be to prepare for life in the streets. A beginning is to do away with voids providing a desolate impression, and get people into the streets. One must find out what people need, and create engagement in society. Preferably, one can try to establish several street cafes scattered around the area, We also recommend to make efforts to improve the microclimate locally, to get a better experience on windy days. In Örestad we find that the available local climate knowledge is not fully used. Then we would have started looking at the universal designs and the potential for improvement in terms of movement patterns of humans. It is not right to focus so much on the architectural, but rather focus more on the functional. It may be an idea to highlight other things than the architect's name and signature buildings. The built environment could with great effect have used several colours and varying expressions. It would make the area more inviting for people, while it would be functional for people with visual impairments. It will give your site more contrasts, which can promote the use of areas further,

\section{Discussion and concluding remarks}

If we look at what topics CEE students from Oslo describe from their study tours of Copenhagen and Malmö, we find that most of the issues from our university courses that deal with sustainable urban development are discussed in the student's field reports. Many students find it interesting to compare Örestad and Western Harbour since these districts are developed during the same period of time, but developed according to somewhat different strategies. Students often used photographs to supplement their reports from the site visits, but many are also seeking additional literature when writing the final reports. From the student feedback, we see that the vast majority seem to have had a great academic benefit of this study tour. They experience phenomena that either do not yet exist in Oslo or are done in other ways than at home. Such field trips make the students more united as a group and they say this creates both a good social and learning environment. Our CEE students obtain through these courses and field trips an interdisciplinary view of sustainable urban development, and are not just focused on whether "resources are used most effectively" as Williams (2010) argues. Our civil engineering students are very concerned with social sustainability issues of urban design, like human scale, security, meeting space and universal design. Many students' reports focused also on traditional civil engineering issues, like sustainable transportation, energy-efficient buildings, pavement quality, stormwater management and local climate. The broad interest of urban design issues probably gives them a better basis for respecting and understanding other professionals they will be cooperating with, in order to promote sustainable urban development. 


\section{References}

[1] J. Goodman, M. Laube, and J. Schwenk, "Curitiba's Bus System is Model for Rapid Transit," Race, Poverty \& the Environment, pp. 75-76, 2005/2006.

[2] C. Landorf, "Evaluating social sustainability in historic urban environments," International Journal of Heritage Studies, vol. 17, pp. 463477, 2011/09/01 2011.

[3] C. J. Lim, "Smartcities," arq: Architectural Research Quarterly, vol. 15, pp. 279-288, 2011.

[4] J. Rabinovitch, "Innovative land use and public transport policy: The case of Curitiba, Brazil," Land Use Policy, vol. 13, pp. 51-67, 1996.

[5] R. Berney, "Learning from Bogotá: How Municipal Experts Transformed Public Space," Journal of Urban Design, vol. 15, pp. 539-558, 2010/11/01 2010.

[6] R. Cervero, O. L. Sarmiento, E. Jacoby, L. F. Gomez, and A. Neiman, "Influences of Built Environments on Walking and Cycling: Lessons from Bogotá," International Journal of Sustainable Transportation, vol. 3, pp. 203-226, 2009/06/23 2009.

[7] K. Williams, "Sustainable cities: research and practice challenges," International Journal of Urban Sustainable Development, vol. 1, pp. 128132, 2010/05/24 2010.

[8] C. Khisty, "Importance of Planning Education for Civil Engineers," Journal of Urban Planning and Development, vol. 113, pp. 54-60, 1987/11/01 1987.

[9] R. Lyles, "Planning Education: Desirable for Civil Engineers?," Journal of Urban Planning and Development, vol. 110, pp. 22-33, 1984/09/01 1984.

[10] R. Camagni, M. C. Gibelli, and P. Rigamonti, "Urban mobility and urban form: the social and environmental costs of different patterns of urban expansion," Ecological Economics, vol. 40, pp. 199-216, 2002.

[11] S. Tsenkova and R.-M. Damiani, "Urban sustainability: learning from evaluation of community plans in Calgary," canadian Journal of Urban Research, 2009.

[12] P. R. Berke and M. M. Conroy, "Are We Planning for Sustainable Development?," Journal of the American Planning Association, vol. 66, p. 21, 2000.

[13] P. R. Berke, D. R. Godschalk, E. J. Kaiser, and D. A. Rodriguez, Urban Land Use Planning. Urbana and Chicago: University of Illinois Press, 2006.

[14] S. Myllylä and K. Kuvaja, "Societal premises for sustainable development in large southern cities," Global Environmental Change, vol. 15, pp. 224$237,2005$.

[15] E. Jepson and M. Edwards, "How Possible is Sustainable Urban Development? An Analysis of Planners' Perceptions about New Urbanism, Smart Growth and the Ecological City," Planning Practice \& Research, vol. 25, pp. 417-437, 2010. 
[16] L. Sandercock, "Out of the Closet: The Importance of Stories and Storytelling in Planning Practice," Planning Theory \& Practice, vol. 4, pp. 11-28, 2003/01/01 2003.

[17] C. Abbott and S. Adler, "Historical Analysis as a Planning Tool," Journal of the American Planning Association, vol. 55, pp. 467-473, 1989/12/31 1989.

[18] J. Gehl, Livet mellem husene : udeaktiviteter og udemiljøer, 6. udg. ed. København: Arkitektens Forlag, 2007.

[19] C. Wang and M. A. Burris, "Photovoice: Concept, Methodology, and Use for Participatory Needs Assessment," Health Education \& Behavior, vol. 24, pp. 369-387, June 1, 1997.

[20] C. N. Sørensen, A.-S. Lütken, C. Erikshøj, M. Landgren, and C. Uebel, "Indicators as Tool for Evaluating the Sustainability of Ørestad Nord and Ørestad City," in 3rd International Workshop on Design in Civil and Environmental Engineering, Kongens Lyngby, Denmark, 2014.

[21] T. Sangild, "Ingen butikker i Ørestaden," in Torben Sangilds Weblog vol. 2016, T. Sangild, Ed., ed, 2007.

[22] L. Olsson and J. Loerakker, "The story behind failure: Copenhagen's business district Örestad," FA - Failed Architecture, vol. 12 September, 2013.

[23] K. B. Christensen, "Örestaden risikerer at ende som ghetto [ Örestaden is at risk at ending as a ghetto]," in Avisen DK, ed, 2010. 